\title{
Oral Paste in Sachet
}

National Cancer Institute

\section{Source}

National Cancer Institute. Oral Paste in Sachet. NCI Thesaurus. Code C149718.

Medicinal product consisting of an oral paste presented in a sachet. 